Pre-proof author version

\title{
Towards a critical psychology of human-animal relations
}

\section{Link to published version: \\ https://onlinelibrary.wiley.com/doi/10.1111/spc3.12375\#spc312375-note-0008}

DOI: $10.1111 / \mathrm{spc} 3.12375$

Please cite as Adams M. (2018) Towards a critical psychology of human-animal relations. Social \& Personality Psychology Compass; e12375.

https://doi.org/10.1111/spc3.12375

\section{Matthew Adams}

University of Brighton

Correspondence

Matthew Adams, School of Applied Social

Science, Mayfield House, University of

Brighton, Falmer BN1 9PH, UK.

Email: matthew.adams@brighton.ac.uk

\begin{abstract}
This article argues that critical psychological engagement with the field of humananimal relations is largely absent, but of potential significance, and begins to outline more concretely what such a perspective might contribute, especially as a form of social psychology. The article provides a brief overview of the emerging psychology of human-animal relations and the extent to which it emphasises situated humananimal interactions in real-world settings, including from the standpoint of animal participants. Recent elaborations of the "animal turn" outside of the discipline of psychology are considered, as they place fresh emphasis on human-animal interaction and interdependence and might further extend the boundaries of what counts as relations that matter in critical and social psychology. These foundations are argued to offer an invitation to critical psychology to engage more fully in the study of human-animal relations and enliven it as a result.
\end{abstract}

Keywords: human-animal, more-than-human, multi-species, nonhuman, posthuman, speciesism, trans-species

\section{INTRODUCTION}

To understand what animals have to say all the resources of science and of the humanities have to be put to work

Bruno Latour

Human nature is an interspecies relationship. 
Other species are fundamentally implicated in the activities of our own- "woven into the fabric of our social, political and psychological lives" (Birke, 2010, p. 338)—as metaphors, projections, stories, but also materially, as others we relate to and interact with in many different ways. Haraway's list of "human-animal worlds" where "ordinary beings-in-encounter" takes place is comprehensive: "in the house, lab, field, zoo, park, truck, office, prison, ranch, arena, village, human hospital, slaughter house, vet clinic, stadium, barn, wildlife preserve, farm, city streets, factory, and more" (Potts \& Haraway, 2010, p. 322). ${ }^{1}$ Human-animal relations are complex, precarious, and fraught with paradox. The specific elements of Haraway's worlds, and the ways in which we conceptualise them, depend upon the society and culture in which we live (Descola, 2013), but also the psychological, interpersonal, and situational contexts through which human-animal relations are embodied, negotiated, and challenged (DeMello, 2012). They are fundamentally defined by power-involving socially structured hierarchy, oppression, injustice, and inequality (Carter \& Charles, 2016; Cudworth, 2015). But they are also constituted by shared enjoyment, work, companionship, and loss (Haraway, 2008). Defined thus, humananimal relations are a topic that should be of great interest to avowedly critical psychologists for whom relationality, situatedness, and power are integral to conceptualising experience and behaviour (Fox, Prilletensky, \& Austin, 2009). Furthermore, a focus on nonhuman animals in relation to human animals offers a fascinating challenge to accepted understandings of who and what counts as meaningful participants in social relations in social psychology more generally.

However, at the turn of the century, after acknowledging the scope and diversity of psychology, Melson (2002) was willing to risk a single generalisation about the discipline as a whole: "the study of human-animal relationships historically has been ignored and continues to resist attention" (p. 347). Between then and now, this lament has been echoed on various occasions (Birke, 2010; Serpell, 2009; Shapiro, 2017). ${ }^{2}$ The same has been said of social psychology in particular (Abell, 2013), in this case arguably reflecting the way the sub-discipline is fundamentally defined. Though definitions of the social in social psychology have always varied, they have tended to agree that it is exclusively about the study of the human, a point made obvious by a glance at any textbook definition, e.g., "the branch of psychology dedicated to the study of how people think about, influence and relate to each other" (Sutton \& Douglas, 2013, p. 7). When they do make an appearance, nonhuman animals are presented as of interest to social psychologists only as rudimentary analogies_- "some general principles" may be transferable but not "as a rule" (Hogg \& Vaughan, 2013, p. 4). The related dismissal of the study of animals being of value only if we are interested in the "evolutionary origins" (Hogg \& Vaughan, 2013, p. 4) of human behaviour obscures the possibility that nonhuman and human animals reciprocally and meaningfully interact, relate, reciprocate, or share a contemporaneous social present (and past) in any meaningful sense. The present social behaviour of animals can only reveal the traces of our past behaviour. 
Thus, in frontline assertions of what social psychology is about, it is still the case that animals are removed from the field of social relations (and, by implication, the situational, political, historical, and cultural), leaving humans as the only legitimate players.

\section{THE EMERGING PSYCHOLOGY OF HUMAN-ANIMAL RELATIONS}

However, this does not tell the whole story. There have long been notable exceptions in theory and research attempting to bring animals into the domain of psychology and sister disciplines (Davis \& Balfour, 1992; Franklin, 1999; Netting, Wilson, \& New, 1987; Serpell, 1986). The growing field of conservation psychology, meanwhile, stresses human-nature relations geared towards the goal of environmental sustainability (Saunders, 2003; Saunders, Brook, \& Eugene Myers, 2006). Human-animal relations mainly feature in conservation psychology in terms of how different forms of human interaction with animals might improve physical and emotional well-being in humans (Clayton \& Brook, 2005), or how they facilitate sustainable behaviour or a connection to nature more generally (Vining, 2003). The study of "zoo experiences" has notably addressed how this particular form of human-animal encounter might nurture stronger connections to, and a desire to care for, animals and nature more generally (Bruni, Fraser, \& Schultz, 2008; Clayton, Fraser, \& Burgess, 2011; Kazdin, 2009).

More recently, it has been claimed that a "psychology of human-animal relations" is now emerging as a distinct field (Amiot \& Bastian, 2015). Some of this work is aligned with established social psychology topics, for example, social categorisation of nonhuman animals (Bastian, Costello, Loughnan, \& Hodson, 2012; Bratanova, Loughnan, \& Bastian, 2011; Dhont, Hodson, Costello, \& Maclnnis, 2014; Loughnan, Haslam, \& Bastian, 2010; Piazza, Landy, \& Goodwin, 2014); "speciesism" as an attitude construct or basis for ingroup and outgroup identifications, prejudice, and discrimination (Costello \& Hodson, 2014, 2010; Dhont et al., 2014; Dhont, Hodson, \& Leite, 2016; Sevillano \& Fiske, 2016); and associated behaviour (Bastian et al., 2012; Bastian \& Loughnan, 2016; Dhont \& Hodson, 2014).

Clearly, aspects of this research orbit the established concerns of mainstream social psychology (and conservation psychology), but in their comprehensive review, Amiot and Bastian (2015) claim a distinctiveness for the field in its own right: "it directly captures the links and the dynamic interplay between humans and animals. The focus, therefore, of human-animal relations research is on reciprocal and interactive relations between humans and animals" (p. 6). However, while Amiot and Bastian clearly articulate and comprehensively thematise this emerging field, what they survey offers a fairly limited take on human-animal relations - if we understand relations to mean reciprocal encounters, interactions, and communication between 
humans and animals in real-life contexts-despite the promise that this is precisely what makes the field distinctive. No doubt this absence reflects the focus of the near200 papers cited-largely experimental and quasi-experimental by design (less than $10 \%$ involved any qualitative element); mostly concerned with measuring human attitudes towards, attachments to, perceptions, and categorisations of nonhuman animals; and/or the effects of animals on humans; and what was missed-interesting work directly relevant to an emerging psychology of human-animal relations but not necessarily in mainstream journals or filed obviously under "psychology" (e.g., Abell, 2013; Fuentes, 2010). Animals are rarely actually present in the methodological procedures of the research cited by Amiot and Bastian, nor ontologically present as contributing to and experiencing that interaction in mutually constitutive ways. Similarly, although animals arepresent in some of the research under the heading of conservation psychology cited above (e.g., zoo visits), an emphasis on their role as active subjects in encounter is rare.

Sanders' dismissal of G.H. Mead's depiction of human-animal communication well over a century ago might seem appropriate here-"people interact[ing] with animalsas-objects" (cited in Wilkie, 2015, p. 325) - though perhaps this is a little harsh. Studies are emerging, for example, that acknowledge how human perception of animals has consequences for how "we" treat "them" in routine everyday contexts, which in turn further shapes perception and justifies that treatment (Sevillano \& Fiske, 2016). Nonetheless, much of the work in these emerging fields still appears to largely understand animals to be outside of the socialdynamics involved, present primarily as the passive recipients of particular framings and social categorisations or active predominantly in the ways they can impact on human variables. A critical and fully social psychology of human-animal relations demands theories and methods that more fully account for reciprocal interaction, from both "sides" (Shapiro, 2017); for how these interactions are formative for all involved; and for how they are implicated in broader political, social, cultural dynamics and power relations. A genuine shift of emphasis towards "reciprocal and interactive relations" involves not just a consideration of "how we interact with and relate to animals" but how, why, and when they interact with and relate to us.

\section{TOWARDS A CRITICAL PSYCHOLOGY OF HUMAN-ANIMAL RELATIONS}

What is the alternative? My argument here is that the tenets of critical (and critical social) psychology, as far as they can be agreed upon, can lend themselves to a creative and critical stretching of the psychology of human-animal relations, while ongoing work outside of psychology can challenge and extend the concerns of a fledgling critical psychology in this area. Regarding the first point, an important overarching orientation in critical psychology is an "assumption of relationality" (Stanley, 2012, p. 636). As articulated by Gergen $(2009,2011)$, such an approach conceptualises experience as an "outcome or expression of fundamental 
relatedness" and displaces the individual as "the primary source or ontological foundation of being" (both Gergen and Hosking, cited in Stanley, 2012, p, 636). A consideration of relationality extends to other shared concerns of critical psychology, including the deconstruction of taken-for-granted but historically, socially, and situationally contingent categories through which we relationally make sense of reality (Gough, 2017); highlighting, understanding, and addressing the workings of power (Elder-Vass, 2012; Ibañez \& Iñiguez, 1997); especially in terms of the way inequalities and injustices intersect to permeate and structure social relations (Bowleg, 2017); and for how power is challenged and resisted, especially by people and groups who are oppressed and marginalised (Fox et al., 2009).

However, to date, avowedly critical psychological approaches have made few inroads into a consideration of human-animal relations, despite numerous precedents being set (e.g., Opotow, 1993; Plous, 1993; Serpell, 1986, 2009). While critical psychology has challenged the individualist ontology of mainstream psychology and has had a hand in the development of an alternative, relational, and dialogical ontology, which, it is argued, better reflects the reality of being-in-the-world (Gergen, 2009), the theoretical development of "relational being" has also taken place within an exceptionally human conceptual framework (e.g.,

Gergen, 2015, 2016). The task in hand then is to make a case for how a psychology of human-animal relations might benefit from the application of the tenets of critical psychology and to outline developments in the study of human-animal relations elsewhere that might have generative outcomes for the field of critical psychology.

\section{THE "ANIMAL TURN" AND A HUMAN-ANIMAL RELATIONAL ONTOLOGY}

The challenge for a critical psychology of human-animal relations is to embrace the deeper "animal turn" discernible in the last decade or so in the humanities and sciences (Shapiro, 2017). Shapiro (2017) expresses this as "a shift from a major focus on the social construction of other animals to attempts to get at 'animals as such', as they actually experience the world" (p. 3), and, we might add, as they experience it in relation to and with humans (Despret, 2013). To consider "animals as such" as participants in social relations requires radically rethinking how we approach human-animal relations conceptually/ontologically and methodologically in psychology. To do so takes us beyond the task identified by Amiot and Bastiansystematically applying the insights of established psychological topics to humananimal relations. Conceptually, we must imaginatively extend the relational ontology noted above, which is a central tenet of many versions of feminist and critical psychology. A relational ontology, to reiterate, assumes "that the relations between entities are ontologically more fundamental than the entities themselves" (Wildman, 2010, p. 55); "that entities come to exist through relations"; and subsequently, that the individual is no longer conceived of as "a presupposition, but rather as a process" (Collomb, 2011, p. 59). 
There is already plenty of fascinating work beyond and between additional disciplines attempting to extend this logic to incorporate both human and nonhuman entities, hence Shapiro's evocation of an "animal turn" (Despret, 2016; Haraway, 2016; Kohn, 2013; Latour, 2005; Tsing, 2015). Haraway (2014) notes with characteristic eloquence how this has now become a prevalent perspective in the natural sciences: "There has been an explosion within the biologies of multispecies becoming with; understanding that to be a one at all you have to be a one of many, and that is not a metaphor; it is about the tissues of being anything at all; and that those who are have been in relationality all the way down". Wolfe's (2010) version of posthumanism similarly asserts "a shared trans-species being-in-the-world constituted by complex relations of trust, respect, dependence, and communication" (p. 141). We also see attempts to articulate a human-nonhuman relational ontology in fields as diverse as archaeology (Watts, 2013), anthropology (Dugnoille, 2014; Kirksey \& Helmreich, 2010; Kohn, 2013; Latour, 2014), geography (Whatmore, 2006; Wright, 2015), sociology (Charles, 2014; Cudworth, 2015; McCarthy, 2016; Sanders, 2007; Wilkes, 2013; York \& Longo, 2017) criminology and legal studies (e.g., Agnew, 1998; Sollund, 2011); philosophy and cultural studies (Haraway, 2003; Litchfield, 2013; Plumwood, 2002); natural history (Henderson, 2012); feminism (Adams, 2015; Kemmerer, 2011; Potts, 2010); and the growing interdisciplinary field of human-animal studies (HAS) (Birke \& Hockenhull, 2012; DeMello, 2012; Peggs, 2012; Wilkie, 2015)—dedicated to finding "new ways of thinking about animals and about human-animal relationships" (Potts, 2010, p. 291). Evidence of a growing understanding of interrelatedness incorporates animals, but also extends to other nonhuman forms, beings, things, places, and elements of the more-thanhuman world (Anderson, Adey, \& Bevan, 2010; Bawaka Country et al., 2016; Ingold, 2005). ${ }^{3}$

\section{SPECIESISM AND TRANS-SPECIES PSYCHOLOGY}

An additional rallying point for the development of a critical psychology of humananimal relations is the conceptualisation of speciesism - "the taken-for-granted belief that humans are superior to and have the right to dominate all other creatures, and that 'humanity' alone bears the hallmarks of intelligence and sentience" (Potts, 2010, p. 292). ${ }^{4}$ Others take the concept of speciesism beyond individual belief or attitude, to argue that it is also deeply inscribed in language, culture, and society (Carter \& Charles, 2016; Cole \& Morgan, 2011); clearly echoing the tenets of critical psychology. Bradshaw and Watkins (2006) go as far as to state that "human-animal differencing comprises much of what defines western human collective identity and an ego construct based on what animals are presumed to lack" (p. 7). ${ }^{5}$ Speciesism at this level is argued to be embedded in the material and structural patterning of societies and subjectivities. It is evident in, for example, the discursive objectification of animals and the associated denial of agency (Adams, 2010), which is in in turn inseparable from the rationalisation and routinisation of animal violence and killing in industrial agriculture (Cudworth, 2015). 
In fact, the most significant point of human-animal interaction in terms of global scale and scope is farming (Cudworth, 2015; Potts \& Haraway, 2010), allied with the slaughter and butchery industries (Hamilton \& McCabe, 2016; see Footnote 1). Of all the domesticated animals alive at any moment, $99 \%$ are animal agriculture commodities (Cudworth, 2015, p. 1; Williams \& DeMello, 2007). Cudworth cites a body of research which documents the routinised animal violence and killing involved in the industrial farming of animals. As she states, "the statistics are of staggering proportions": At least 55 billion land-based nonhuman animals are killed in the global farming industry annually, and this figure is growing year-on-year. ${ }^{6}$ Yet in established coverage of human-animal relations as a psychological topic, the chains of interaction that constitute industrial agriculture are only beginning to feature as points of interaction, with an emphasis on individuals who eat meat (Bastian \& Loughnan, 2016; Dhont \& Hodson, 2014)—pets, therapy, zoos, parks, and wilderness are much more likely focal points (e.g., Clayton \& Myers, 2009).

Recent experimental research has operationalised the concept of speciesism as a psychological variable, raising interesting questions about the intersections between speciesism and other forms of prejudice, even if it tends to individualise them (e.g., Bastian et al., 2012; Bratanova et al., 2011; Costello \& Hodson, 2014; Dhont et al., 2014; Loughnan et al., 2010). Trans-species psychology, by contrast, is a recent development which consolidates a critique of speciesism in aligning itself with "liberation psychology"-a term familiar to critical psychologists (Bradshaw \& Watkins, 2006). It is normally applied to human suffering in the context of colonialism, patriarchy, and capitalism and claims that psychology should be utilised to highlight and challenge the "oppression, marginalization, exploitation, forced migration, and genocide that animal communities experience" (Bradshaw \& Watkins, 2006, p. 2). Bradshaw (2010) cites Ignacio Martín-Baró's claims about liberation psychology: "If we want psychology to make a significant contribution to the history of our peoples... we have to redesign our theoretical and practical tools, but to redesign them from the standpoint of the lives of our own people: from their sufferings, their aspirations, and their struggles" and simply adds that "the same holds when considering other species" (p. 416).

In wedding speciesism with the conceptualisation of intersectionality, feminist theory has taken this argument further (Jones, 2010; Parry, 2010; Potts, 2010;

Twine, 2010). Intersectionality refers to "the ways in which different forms of prejudice, oppression and marginalization are intricately connected and cannot effectively be addressed without reference to their interrelationships" (Potts, 2010, p. 295). Adams $(1994,2015)$ has been at the forefront of work in this area, making the link between, for example, cultural constructions of masculinity and eating meat, and the objectification of women and animals (Cudworth, 2011). These are not coincidentally similar social categories, they are "interlocking constructions of difference" which reflect and maintain hierarchies of power and control (Twine, 2010, p. 398). Similarly, "dehumanisation" discourses legitimatising the exploitation and 
oppression of others "makes sense only in the context of the routine exploitation of animals" (Jones, 2010, p. 371). As Potts (2010) states, "the discrimination and maltreatment of nonhuman species occurs in relation to, and is complicit with, other forms of oppression, prejudice and marginalization affecting humans" (p. 299). Rather than approaching human-animal relations as a separate issue from the existing concerns relating to exploitation, inequality, and injustice then, intersectionality encourages critical psychologists to search for the points of connection between them.

To return to trans-species psychology, besides offering a critique of speciesism, it proposes a constructive alternative that explicitly asserts a trans-species relational ontology by emphasising interdependencies and interrelationships between humans and other species in theory and research (e.g., Bradshaw, Capaldo, Lindner, \& Grow, 2008; Bradshaw \& Watkins, 2006; Buckley \& Bradshaw, 2010). We might characterise trans-species psychology as an attempt to foster a relational ontology that extends beyond species boundaries, in a way that underpins and informs its more overtly political project of challenging speciesism and that connects directly with the "animal turn" underway in the humanities, social, and natural sciences noted above. Exposing critical psychology to these radical developments means more than just acknowledging that nonhuman animals shuffle on to the stage of social existence from time to time. It means recognising "that we only can begin to understand what it means to be human and animal from the situational and positional fluidity of the human-animal divide as revealed through human-animal interactions" (McNiven, 2013, p. 98).

\section{HUMAN-ANIMAL METHODOLOGIES}

Framing human-nonhuman animal relations in terms of speciesism is an invitation for critical theoretical perspectives and methodological approaches to contribute to a "climate of problematisation" (Curt, 1994) and an "unsettling [of] mainstream practices" (Tuffin, 2005, p. 167). Discourse analysis, for example, might be utilised to evidence claims about speciesism as pervasive, taken-for-granted, and culture-wide, whether in everyday conversations, newspapers, advertising, online, or in industry documents (Arcari, 2016; Cole \& Morgan, 2011; Morgan \& Cole, 2011; Sneijder \& Te Molder, 2005; Stibbe, 2001). To analyse the embeddedness of ideologies in banal, everyday forms is to follow a now established strand in critically oriented social psychology (Billig, 1995). A critical impetus shifted the focus of psychologies of prejudice and discrimination away from a reductive focus on internal traits and states, towards the realm of shared language and social construction (Wetherell \& Potter, 1992). It can make a similar move in addressing how humans collectively construct contingent, motivated, understandings of mutually reinforcing categories that have material implications for self and (nonhuman) other. 
All this said, a social constructionist and discursive orientation might still be concerned exclusively with how humans construct animals, even if it is also committed to understanding the implications of those constructions for animals (human and nonhuman). How to translate a commitment to a relational ontology that includes human and nonhuman animals into a methodology? In making sense of human-animal relations as multidirectional, we cannot readily presume ready access to a shared system of language or other forms of symbolisation (though see Alger \& Alger, 2003, 1999). Critical psychology has leaned heavily (though not exclusively) towards qualitative methods, focusing on interaction and communication, especially language-based (Braun, Clarke, \& Gray, 2017). Yet Shapiro (2017) holds out hope for qualitative methods, including discursive, in that they "rely on the objects of or, better, partners in a study being subjects - that is having these structures of experience - and thereby being accessible either through direct communication or expressive behavior" (p. 4). We might add that qualitative methods in psychology have increasingly strived to incorporate embodied, prelinguistic, and other-thanlanguage forms of experience and relatedness-as aspects of reality as it is subjectively and interpersonally experienced (Langdridge, 2017). It has also championed participatory and action-oriented research methods, working with marginalized groups or communities, to challenge injustice and facilitate social change (Burton \& Kagan, 2005).

Striving to find a channel for beings constituted as "others" to be represented, expressed, communicated, through sympathetic interpretation and/or on their own terms, is a reasonable basis for developing "new forms of listening," and attunement to "alternative modalities of communication" (Bradshaw \& Watkins, 2006, p. 14; see also Brigstocke \& Noorani, 2016). The work of devising the methodological tools to do this is far from settled (Dowling, Lloyd, \& Suchet-Pearson, 2016). However, we need not wait for a "pure" form of listening or communicating, as no doubt we will always remain on the "anthropocentric side" in studying such relations (Bernacchi, 2013 p. 144). A practical step for a meaningful and productive research agenda in the field is the study of the dynamics of human-animal relations in different real-life social settings, whether this be observing present-day practices or pursuing historical case studies (Charles, 2014; Hamilton \& McCabe, 2016). This study is underway in related disciplines, extending two methods-ethnography and participatory research - that are established tools in critical and qualitative psychology (e.g., Case, Todd, \& Kral, 2014; Tolman \& Brydon-Miller, 1997; Willig \& Stainton-Rogers, 2008).

The first, multispecies ethnography, emerges from anthropology. It encompasses "ethnographic research and writing that is attuned to life's emergence within a shifting assemblage of agentive beings" (Ogden, Hall, \& Tanita, 2013, p. 6) and strives "to place a fresh emphasis on the subjectivity and agency of organisms whose lives are entangled with humans" (Kirksey \& Helmreich, 2010, p. 545). Attunement and listening — these are two of the required qualities highlighted above 
as requirements of a trans-species psychology. In practice, multispecies ethnographies to date involve paying greater attention to "research sites that foster multispecies encounters" (Ogden et al., 2013; p. 7) such as those found in Haraway's list of "human-animal worlds" described earlier. Ethnographic techniques are applied to explore how multiple species actively contribute to the constitution of the social reality being studied.

Examples include the study of human and macaque monkey interaction in shared spaces in Bali (Fuentes, 2010); human-horse "co-domestication" in horse riding communities (Maurstad, Davis, \& Cowles, 2013; see also Birke \& Hockenhull, 2012; Despret, 2013); and ethnographies of workplaces defined by human-nonhuman animal interaction such as abattoirs, laboratories, and farms (Birke, 2003; Hamilton \& McCabe, 2016). Much of this work explicitly strives to provide "case studies that place value on more-than-human animals as genuine dialogic participants in the world" (Schutten, 2015, p. 2), but there are also explicit attempts to incorporate many other species, beings, and things, including plants and microorganisms (e.g., Tsing, 2012), easily neglected by a focus on "human-animal" alone (Smart, 2014). Many different logics are drawn upon to interpret and frame these encounters, including Latour's network theory (2005; e.g., Nimmo, 2011, 2010), Deleuze and Guatarri's (1987) rhizome (e.g. McLeod, 2014), and Haraway's $(2003,2008)$ conceptualisation of companion species (e.g., Lorimer, 2010). ${ }^{7}$

More-than-human participatory research is mostly closely associated with human geography (Bastian, Jones, \& Moore, 2016) and attempts to pay closer attention to the ways in which the agency of nonhuman entities "saturates our research interactions" (Wright et al., 2012 p. 52). Work to date involves place-based collaboration with indigenous practitioners to generate relational narratives of human and more-than-human "emergent belonging" (Wright, 2015); though Bastian et al. (2016) open up a number of future directions that such a methodology might take. There are earlier precedents. More-than-human participatory research proposes a form of co-operative inquiry that parallels the earlier development of participatory action research (PAR), now an established approach in community and critical psychology (Brydon-Miller, 1997). In fact, since the first edition of Reason and Bradbury's Handbook of Action Research (2001), the "skills" of co-operative enquiry have included "empathy, resonance and attunement, participating in the way of being of other people and the more-than-human world ... it is about being open to the meaning we give to and find in our world" (Heron \& Reason, 2001, p. 184).

Such skills are especially important at the trans-species level, where researcher and participant cannot depend on a shared language as a basis for communication. Without it, the researcher must rely on sympathetic observation of animals and/or listening to the narratives of those humans who live and work closely with them (Merskin, 2011)—which returns us to the same methodological ground as multispecies ethnography. The only significant difference is that the goals of PAR 
perhaps allow the researcher to more explicitly frame their work in politicoethical terms, and therefore more readily aligns it with trans-species psychology, i.e., "to ask questions in service of those one is speaking of and engaging with so that the desires of that group can be advanced by the initiating actions that transform the current state of affairs into one that would be more desirable from the participants' point of view" (Merskin, 2011, p. 147). These are just two broad extensions of methodological approaches, and as practical tools, they are still in their infancy and advocated with caution. But they will be familiar to those with an interest in critical psychology and might appeal to some as having the potential to further explore the complexities and human-animal social relations.

\section{CONCLUSION}

Why do we need a critical psychology of human-animal relations? After all, there are some established topics, such as animal-assisted therapy, growing mainstream coverage (e.g., Clayton \& Myers, 2009), and an emerging psychology of humananimal relations has been identified (Amiot \& Bastian, 2015). We need it because there are still important questions to ask about how the relationships between human and animals should be conceptualised and studied in psychology. First, we must accept that there is more at stake than the successful application of psychological knowledge to a historically neglected topic area. While there is great benefit in thinking of human-animal relations as subject to similar psychological dynamics as human-human relations-be it attachment, intergroup processes, or helping behaviour (Amiot \& Bastian, 2015) — there are wider, arguably more important implications. Human-animal relations are central to pressing environmental and welfare issues, including industrial animal farming (in terms of ethical and welfare issues and its contribution to environmental damage and climate change), species loss and habitat destruction (land, water, and air), and associated loss of biodiversity. The concept of the Anthropocene-a proposed definition of a new epoch to mark the unprecedented influence of human activity on all forms of planetary life (Steffen et al., 2011; Steffen, Crutzen, \& McNeill, 2007)—in particular is an invitation to question human-animal and human-nonhuman boundaries and develop models of reciprocity and interdependence (Adams, 2017). Taking humananimal relations seriously means addressing how those relations embody and are embedded in intersecting social, political, and psychological processes.

I make the call for a critical and social psychology of human-animal relations here not merely to fill a gap in the literature then but because it is part of an urgent political project which can only be addressed through transformative social change. The loss of biodiversity, decimation and destruction of countless species, and wider ecological devastation that herald the Anthropocene are a reflection of the profound interrelatedness of human-nonhuman and point to the necessity of finding ways to foster more equitable, just, and sustainable relations (Abell, 2013; Bekoff \& Bexell, 2010). The challenge is formidable, but "we must somehow... reinvent the 
conditions for multispecies flourishing... in a time of human-propelled mass extinctions and multispecies genocides that sweep people and critters into the vortex" (Haraway, 2016, p. 130).

Kidner (2001) recognised, back at the turn of the century, that the "discontinuity between the 'animal' and 'human' realms is beginning to come under fire" (p. 94), a process that has hastened ever since. It is a trajectory reflected in diverse activities and forms, including the academic disciplines described above, but also in contemporary fiction, film-making, photography, journalism, activism, and campaigning. ${ }^{8}$ As a society, we are increasingly placing our relationship to other species under close scrutiny, amplified by the growing awareness of unprecedented human influence on planetary life, often with devastating results. I have argued that this situation requires us, as critical and social psychologists, to more fully extend our understanding of the social and the psychological beyond the species barrier into terrain that is increasingly being occupied by ideas and arguments that are pressing in on the discipline from all sides.

\section{Biography}

Matthew Adams works in the School of Applied Social Sciences at the University of Brighton. His research in recent years has focused on various aspects of the interrelationship between ecology, subjectivity, and society and has published various articles on these issues. His most recent book-Ecological Crisis, Sustainability and the Psychosocial (2016, Palgrave Macmillan)—is a development of these interests. It is a consideration of the contribution critical and interdisciplinary perspectives (including critical social psychology) can make to our understanding of human engagement with anthropogenic ecological crisis. His next bookAnthropocene Psychology: Being human in a More-than-human World(Routledge, 2018) -will develop these themes further. He teaches mostly social and environmental psychology with a critical orientation.

\section{References}

Adams, C.J. (2015 [1990]) The sexual politics of meat: A feminist-vegetarian critical theory. Bloomsbury Publishing USA.

Adams, C. J. (2010). Why feminist-vegan now? Feminism \& Psychology, 20(3), 302-317.

Adams, C. J. (1994). Bringing peace home: A feminist philosophical perspective on the abuse of women, children, and pet animals. Hypatia, 9(2), 63-84. 
Adams, M. (2017). Environment: Critical social psychology in the Anthropocene. In B. Gough (ed.) The Palgrave Handbook of Critical Social Psychology. Basingstoke: Palgrave Macmillan. pp. 621-641.

Agnew, R. (1998). The causes of animal abuse: A social-psychological analysis. Theoretical Criminology, 2(2), 177-209.

Alger, J., \& Alger, S. (2003). Cat culture: The social world of a cat shelter. Philadelphia: Temple University Press.

Alger, J. M., \& Alger, S. F. (1999). Cat culture, human culture: An ethnographic study of a cat shelter. Society \& Animals, 7(3), 199-218.

Amiot, C. E., \& Bastian, B. (2015). Toward a psychology of human-animal relations. Psychological Bulletin, 141(1), 6-47.

Anderson, J., Adey, P., \& Bevan, P. (2010). Positioning place: polylogic approaches to research methodology. Qualitative Research, 10(5), 589-604.

Arcari, P. (2016). Normalised, human-centric discourses of meat and animals in climate change, sustainability and food security literature. Agriculture and Human Values, 1-18.

Bastian, M., Jones, O., \& Moore, N. (Eds.). (2016). Participatory research in more-thanhuman worlds. New York: Taylor \& Francis.

Bastian, B., \& Loughnan, S. (2016). Resolving the meat-paradox: A motivational account of morally troublesome behavior and its maintenance. Personality and Social Psychology Review. 21(3), 278-299.

Bastian, B., Costello, K., Loughnan, S., \& Hodson, G. (2012). When closing the humananimal divide expands moral concern the importance of framing. Social Psychological and Personality Science, 3(4), 421-429.

Bawaka Country including S Wright, Suchet-Pearson, S., Lloyd, K., Burarrwanga, L., Ganambarr, R., Ganambarr-Stubbs, M. and Maymuru, D. (2016). The politics of ontology and ontological politics. Dialogues in Human Geography, 6(1), 23-27.

Bekoff, M., \& Bexell, S. M. (2010). Ignoring nature: Why we do it, the dire consequences, and the need for a paradigm shift to save animals, habitats, and ourselves. Human ecology review, 17(1), 70-74.

Bernacchi, L. A. (2013). Flocking: Bird-human ritual communication. In E. Plec (Ed.), Perspectives on human-animal communication: Internatural communication (pp. 143-161). London: Routledge.

Birke, L. (2010). Structuring relationships: On science, feminism and non-human animals. Feminism \& Psychology, 20(3), 337-349. 
Birke, L., and Hockenhull, J. (Eds.). (2012). Crossing boundaries: investigating humananimal relationships (Vol. 14). New York: Brill.

Bowleg, L. (2017). Intersectionality: An underutilized but essential theoretical framework for social psychology. In B. Gough (ed.) The Palgrave Handbook of Critical Social Psychology (pp. 507-529). Palgrave Macmillan UK.

Bradshaw, G. A. (2010). You see me, but do you hear me? The science and sensibility of trans-species dialogue. Feminism \& Psychology, 20(3), 407-419.

Bradshaw, G. A., \& Watkins, M. (2006). Trans-species psychology: Theory and praxis. Psyche \& Nature, 75, 69-94.

Bradshaw, G. A., Capaldo, T., Lindner, L., \& Grow, G. (2008). Building an inner sanctuary: complex PTSD in chimpanzees. Journal of Trauma \& Dissociation, 9(1), 9-34.

Braun, V., Clarke, V., Gray, D. (2017). Innovations in qualitative methods. In B. Gough (ed.) The Palgrave handbook of critical social psychology. Basingstoke: Palgrave. Pp. 243-266.

Bratanova B., Loughnan S., Bastian B. (2011). The effect of categorization as food on the perceived moral standing of animals, Appetite, 57 (1), 193-196.

Brigstocke, J., \& Noorani, T. (2016). Posthuman attunements: Aesthetics, authority and the arts of creative listening. GeoHumanities, 2(1), 1-7.

Bruni, C. M., Fraser, J., \& Schultz, P. W. (2008). The value of zoo experiences for connecting people with nature. Visitor Studies, 11(2), 139-150.

Brydon-Miller, M. (1997). Participatory action research: Psychology and social change. Journal of Social Issues, 53(4), 657-666.

Buckley, C., \& Bradshaw, G. A. (2010). The art of cultural brokerage: Recreating elephanthuman relationship and community. Spring: A Journal of Archetype and Culture, 83, 35-59.

Burton, M., \& Kagan, C. (2005). Liberation social psychology: learning from Latin America. Journal of Community \& Applied Social Psychology, 15(1), 63-78.

Carter, B., \& Charles, N. (2016). The animal challenge to sociology. European Journal of Social Theory, 1368431016681305.

Case, A. D., Todd, N. R., \& Kral, M. J. (2014). Ethnography in community psychology: Promises and tensions. American Journal of Community Psychology, 54(1-2), 60-71.

Charles, N. (2014). 'Animals just love you as you are': Experiencing kinship across the species barrier. Sociology, 48(4), 715-730. 
Clayton, S., \& Brook, A. (2005). Can psychology help save the world? A model for conservation psychology. Analyses of Social Issues and Public Policy, 5(1), 87-102.

Clayton, S., Fraser, J., \& Burgess, C. (2011). The role of zoos in fostering environmental identity. Ecopsychology, 3(2), 87-96.

Clayton, S. and Myers, G. (2009) Conservation psychology: Understanding and promoting human care for nature. London: Wiley-Blackwell.

Cole, M. (2011). From "animal machines" to "happy meat"? Foucault's ideas of disciplinary and pastoral power applied to 'animal-centred' welfare discourse. Animals, 1(1), 83-101.

Cole, M., \& Morgan, K. (2011). Vegaphobia: derogatory discourses of veganism and the reproduction of speciesism in UK national newspapers. The British Journal of Sociology, 62(1), 134-153.

Collomb, C. (2011). Relational ontology and conceptions of the common. Multitudes, (2), 5963.

Costello, K. \& Hodson, G. (2014), Explaining dehumanization among children: The interspecies model of prejudice. British Journal of Social Psychology, 53: 175-197.

Costello, K., \& Hodson, G. (2010). Exploring the roots of dehumanization: The role of animal-human similarity in promoting immigrant humanization. Group Processes and Intergroup Relations, 13, 3-22.

Cudworth, E. (2015). Killing animals: sociology, species relations and institutionalized violence. The Sociological Review, 63(1), 1-18.

Cudworth, E. (2011). 'Most Farmers Prefer Blondes': Social Intersectionality and Species Relations. In B. Carter and N. Charles (eds.) Human and other animals: Critical perspectives, 153-172.

Curt, B. C. (1994). Textuality and tectonics: Troubling social and psychological science. Milton Keynes: Open University Press.

Davis, H. E., \& Balfour, D. A. (1992). The inevitable bond: Examining scientist-animal interactions. Cambridge: Cambridge University Press.

Deleuze, G. \& Guattari, F. (1987). A thousand plateaus: Capitalism and schizophrenia. Trans. B. Masumi. Minneapolis: University of Minnesota Press.

DeMello, M. (2012) Animals and Society: An Introduction to Human-Animal Studies. New York: Columbia University Press.

Descola, P. (2013). Beyond nature and culture. Chicago: University of Chicago Press. 
Despret, V. (2016, trans. By B. Buchanan). What would animals say if we asked the right questions? Minneapolis: University of Minnesota Press.

Despret, V. (2013). Responding bodies and partial affinities in human-animal worlds. Theory, Culture \& Society, 30(7-8), 51-76.

Dhont, K., \& Hodson, G. (2014). Why do right-wing adherents engage in more animal exploitation and meat consumption? Personality and Individual Differences, 64, 12-17. doi: 10.1016/j.paid.2014.02.002

Dhont, K., Hodson, G., \& Leite, A. C. (2016). Common Ideological Roots of Speciesism and Generalized Ethnic Prejudice: The Social Dominance Human-Animal Relations Model (SDHARM). European Journal of Personality, 30(6), 507-522.

Dhont, K., Hodson, G., Costello, K., \& Maclnnis, C. C. (2014). Social dominance orientation connects prejudicial human-human and human-animal relations. Personality \& Individual Differences, 61, 105-108.

Dowling, R., Lloyd, K., \& Suchet-Pearson, S. (2016). Qualitative methods II: 'More-thanhuman' methodologies and/in praxis. Progress in Human Geography, online first, 0309132516664439.

Dugnoille, J. (2014). From plate to pet: Promotion of trans-species companionship by Korean animal activists. Anthropology Today, 30(6), 3-7.

Elder-Vass, D. (2012). The reality of social construction. Cambridge University Press.

Fox, D., Prilletensky I. \& Austin, S. (2009). Critical psychology for social justice. In D. Fox, I. Prilletensky I. \& S. Austin (eds.). Critical psychology: An introduction. London: Sage.

Franklin, A. (1999). Animals and modern cultures: A sociology of human-animal relations in modernity. London: Sage.

Fuentes, A. (2010). Naturalcultural encounters in Bali: Monkeys, temples, tourists, and ethnoprimatology. Cultural Anthropology, 25(4), 600-624.

Gergen, K. J. (2009). Relational being: Beyond self and community. Oxford: Oxford University Press.

Gergen, K. J. (2011). Relational being: A brief introduction. Journal of Constructivist Psychology, 24(4), 280-282.

Gergen, K. J. (2015). Toward a relational humanism. The Journal of Humanistic Counseling, 54(2), 149-165.

Gergen, K. J. (2016). Toward a visionary psychology. The Humanistic Psychologist, 44(1), 3-17. 
Godlovitch, S., Godlovitch, R., \& Harris, J. (1971). Animals, men and morals: An enquiry into the maltreatment of non-humans. London: Victor Gollacnz.

Gough, B. (2017) (ed.) Palgrave Handbook of Critical Social Psychology. Basingstoke: Palgrave.

Hamilton, L., \& McCabe, D. (2016). 'It's just a job': Understanding emotion work, deanimalization and the compartmentalization of organized animal slaughter. Organization, 23(3), 330-350.

Harari, Y. N. (2015). Industrial farming is one of the worst crimes in history. The Guardian, 25 September 2015. Accessed https://www.theguardian.com/books/2015/sep/25/industrialfarming-one-worst-crimes-history-ethical-question

Haraway, D. J. (2016). Staying with the trouble: Making kin in the Chthulucene. Durham, NC: Duke University Press.

Haraway, D. (2014, September 5). Anthropocene, Capitalocene, Chthulucene: Staying with the Trouble. Anthropocene: Arts of living with a damaged planet, AURA: Aarhus University Research on the Anthropocene. https://vimeo.com/97663518

Haraway, D. (2008). When species meet. Minneapolis: University of Minnesota Press.

Haraway, D. J. (2003). The companion species manifesto: Dogs, people, and significant otherness. Chicago: Prickly Paradigm Press.

Henderson, C. (2012). The Book of Barely Imagined Beings: A $21^{\text {st }}$ Century Bestiary. London: Granta.

Heron, J and Reason, P. (2001) The practice of co-operative inquiry: Research 'with' rather than 'on' people. In P. Reason, P. \& H. Bradbury (Eds.). (2001). Handbook of action research: Participative inquiry and practice. London: Sage. Pp. 179-188.

Ibañez, T. \& Iñiguez, L. (1997). Critical Social Psychology. London: Sage.

Ingold, T. (2005) Epilogue: towards a politics of dwelling. Conservation \& Society, 3(2), 5018.

jones, p. (2010). Roosters, hawks and dawgs: Toward an inclusive, embodied eco/feminist psychology. Feminism \& Psychology, 20(3), 365-380.

Kazdin, A. E. (2009). Psychological science's contributions to a sustainable environment: Extending our reach to a grand challenge of society. American Psychologist, 64(5), 339.

Kemmerer, L. A. (Ed.). (2011). Sister species: Women, animals, and social justice. Illinois: UI Press. 
Kidner, D. (2001). Nature and psyche: radical environmentalism and the politics of subjectivity. New York, NY: SUNY.

Kirksey, S., and Helmreich, S. (2010) The emergence of multispecies ethnography. Cultural Anthropology, 25(4), 545-576.

Kohn, E. (2013) How forests think: Toward an anthropology beyond the Human. Berkeley, CA: California: University of California Press.

Latour, B. (2014). On selves, forms, and forces. HAU: Journal of Ethnographic Theory, 4(2), 261-266.

Langdridge, D. (2017). Phenomenology. In B. Gough (ed.) The Palgrave handbook of critical social psychology. Basingstoke: Palgrave. Pp. 165-183.

Litchfield, C. A. (2013). Telling the truth about animals and environments: Media and proenvironmental behaviour. In Crocker, R., \& Lehmann, S. (Eds.). Motivating change: sustainable design and behaviour in the built environment. London: Routledge. Pp. 153-177.

Lorimer, J. (2010). Elephants as companion species: the lively biogeographies of Asian elephant conservation in Sri Lanka. Transactions of the Institute of British Geographers, 35(4), 491-506.

Loughnan, S., Haslam, N., \& Bastian, B. (2010). The role of meat consumption in the denial of moral status and mind to meat animals. Appetite,55(1), 156-159.

Maurstad, A., Davis, D., \& Cowles, S. (2013). Co-being and intra-action in horse-human relationships: a multi-species ethnography of be (com)ing human and be (com) ing horse. Social Anthropology, 21(3), 322-335.

McCarthy, D. (2016). Dangerous dogs, dangerous owners and the waste management of an 'irredeemable species'. Sociology, 50(3) 560-575.

McLeod, K. (2014). Orientating to assembling: Qualitative inquiry for more-than-human worlds. International Journal of Qualitative Methods, 13(1), 377-394.

McNiven, I. J. (2013). Between the living and the dead: relational ontologies and the ritual dimensions of dugong hunting across Torres Strait. Relational Archaeologies: Humans, Animals, Things. In C. Watts, C. (ed.). Relational archaeologies: humans, animals, things. London: Routledge. Pp 97-116.

Melson, G. F. (2002). Psychology and the study of human-animal relationships. Society \& Animals, 10(4), 347-352.

Merskin, D. (2011). Hearing voices: The promise of participatory action research for animals. Action Research, 9 (2),144-161. 
Morgan, K., \& Cole, M. (2011). The discursive representation of nonhuman animals in a culture of denial. In B. Carter and N. Charles (eds.) Human and Other Animals (pp. 112132). Basingstoke: Palgrave.

Netting, F. E., Wilson, C. C., \& New, J. C. (1987). The human-animal bond: Implications for practice. Social Work, 32(1), 60-64.

Nimmo, R. (2011). Actor-network theory and methodology: social research in a more-thanhuman world. Methodological Innovations Online, 6(3), 108-119.

Nimmo, R. (2010). Milk, modemity and the making of the human: purifying the social. London: Routledge.

Ogden, L. A., Hall, B., \& Tanita, K. (2013). Animals, plants, people, and things: A review of multispecies ethnography. Environment and Society, 4(1), 5-24.

Opotow, S. (1993). Animals and the scope of justice. Journal of Social Issues, 49(1), 71-85.

Parker, I., \& Shotter, J. (Eds.). (1990). Deconstructing social psychology. Hove: Psychology Press.

Parry, J. (2010). Gender and slaughter in popular gastronomy. Feminism \& Psychology, 20(3), 381-396.

Peggs, K. (2012). Animals and sociology. New York: Palgrave.

Piazza, J., Landy, J., \& Goodwin, G. (2014). Cruel nature: harmfulness as an important, overlooked dimension in judgments of moral standing. Cognition, 131(1), 108-124.

Plumwood, V. (2002). Environmental culture: The Ecological Crisis of Reason. London: Routledge.

Potts, A. (2010). Introduction: Combating speciesism in psychology and feminism. Feminism \& Psychology, 20, 291-301.

Potts, A., \& Haraway, D. (2010). Kiwi chicken advocate talks with Californian dog companion. Feminism \& Psychology, 20(3), 318-336.

Plous, S. (1993). The role of animals in human society. Journal of Social Issues, 49, 1-9.

Potts, A., \& Haraway, D. (2010). Kiwi chicken advocate talks with Californian dog companion. Feminism \& Psychology, 20(3), 318-336.

Sanders, C. (2007) The sociology of nonhuman animals and society. In: Bryant C and Peck D (eds) 21st Century Sociology. A Reference Handbook, Vol. 2. Thousand Oaks, CA: Sage, 2-7. 
Saunders, C.D. 2003. The emerging field of Conservation Psychology. Human Ecology Review, Vol. 10, No, 2. 137-49

Saunders, C. D., Brook, A. T., \& Eugene Myers, O. (2006). Using psychology to save biodiversity and human well-being. Conservation Biology, 20(3), 702-705.

Serpell, J. A. (2009). Having our dogs and eating them too: Why animals are a social issue. Journal of Social Issues, 65, 633-644.

Serpell, J. A. (1986) In the company of animals: A study of human-animal relationship. Cambridge: Cambridge University Press

Sevillano, V., \& Fiske, S. T. (2016). Warmth and competence in animals. Journal of Applied Social Psychology, 46(5), 276-293.

Shapiro, K. (2017) Human-Animal Studies: Fertile Ground for Qualitative Analysis. Society of Qualitative Investigations in Psychology, May 25, 2017, Fordham University.

Smart, A. (2014). Critical perspectives on multispecies ethnography. Critique of Anthropology, 34(1), 3-7.

Sneijder, P., \& Te Molder, H. F. (2005). Moral logic and logical morality: Attributions of responsibility and blame in online discourse on veganism. Discourse \& Society, 16(5), 675696.

Sollund, R. (2011). Expressions of speciesism: the effects of keeping companion animals on animal abuse, animal trafficking and species decline. Crime, Law and Social Change, 55(5), 437-451.

Stanley, S. (2012), Mindfulness: Towards A Critical Relational Perspective. Social and Personality Psychology Compass, 6: 631-641.

Steffen, W., Persson, Å., Deutsch, L., Zalasiewicz, J., Williams, M., Richardson, K., Crumley, C., Crutzen, P., Folke, C., Gordon, L. and Molina, M., 2011. The Anthropocene: From global change to planetary stewardship. AMBIO: A Journal of the Human Environment, 40(7), pp.739-761.

Steffen, W., Crutzen, P. J., \& McNeill, J. R. (2007). The Anthropocene: are humans now overwhelming the great forces of nature. AMBIO: A Journal of the Human Environment, 36(8), 614-621.

Stibbe, A. (2001). Language, power and the social construction of animals. Society \& Animals, 9(2), 145-161.

Tolman, D. L., \& Brydon-Miller, M. (1997). Transforming psychology: Interpretive and participatory research methods. Journal of Social Issues, 53(4), 597-603. 
Tsing, A. L. (2015). The mushroom at the end of the world: On the possibility of life in capitalist ruins. Princeton, NJ: Princeton University Press.

Tsing, A. (2012). Unruly edges: Mushrooms as companion species for Donna Haraway. Environmental Humanities, 1(1), 141-154.

Tuffin, K. (2005). Understanding critical social psychology. London: Sage.

Twine, R. (2010). Intersectional disgust? Animals and (eco) feminism. Feminism \& Psychology, 20(3), 397-406.

Vining, J. (2003). The connection to other animals and caring for nature. Human Ecology Review, 10(2), 87-99.

Watts, C. (ed.) (2013). Relational archaeologies: humans, animals, things. London: Routledge.

Wetherell, M., \& Potter, J. (1992). Mapping the language of racism: Discourse and the legitimation of exploitation. Columbia University Press.

Whatmore, S. (2006). Materialist returns: practising cultural geography in and for a morethan-human world. Cultural Geographies, 13(4), 600-609.

Whitehead, H., \& Rendell, L. (2014). The cultural lives of whales and dolphins. Chicago: University of Chicago Press.

Wildman, W. J. (2010). An introduction to relational ontology. In J. Polkinghorne (ed.) The Trinity and an entangled world: Relationality in physical science and theology, pp. 55-73. Grand Rapids, Ml: Eerdmans.

Wilkie, R. (2015) Multispecies scholarship and encounters: Changing assumptions at the human-animal nexus. Sociology 49(2): 323-339.

Williams, E. E., \& DeMello, M. (2007). Why animals matter: the case for animal protection. Amhurst, NY: Prometheus Books.

Willig, C. \& Stainton-Rogers, W. (2008). Ethnography. In Willig, C. \& Stainton-Rogers, W. The Sage handbook of qualitative research in psychology (pp. 15-31). London: Sage

Wise, S. M. (2015). Animal Rights, Animal Wrongs. Foreign Affairs. April 282015. Accessed here https://www.foreignaffairs.com/articles/2015-04-28/animal-rights-animalwrongs

Wolfe, C. (2010). What is posthumanism? Minnesota: University of Minnesota Press.

Wright, S. (2015). More-than-human, emergent belongings: A weak theory approach. Progress in Human Geography, 39(4), 391-411. 
York, R. and Longo, S.B (2017) Animals in the world: A materialist approach to sociological animal studies. Journal of Sociology 53(1), $32-46$.

\footnotetext{
${ }^{1} \mathrm{~A}$ consideration of primary points of interaction also reveals the extent and variety of human-animal relations: in the consumption of food (meat, milk, eggs) - by humans, but also by other animals in different settings; as companions, guides and partners (pets, therapy, sight and hearing guides, agility); as servants and/or sources of labour (horse power, transportation, messengers); clothing and ornament (such as trophies, shoes, handbags); experimental subjects (psychology, medicine, cosmetics); as spectacle and entertainment (zoos, aquariums, circuses, hunting, racing, fighting). ${ }^{2}$ There are exceptions - two relatively established areas in psychology that explicitly address humananimal relations (Potts, 2010). The first is the study of the health benefits (almost exclusively for humans) of contact with animals - in variations of animal-assisted therapy; and less formally, e.g. contact with household pets. This field has developed in parallel with the growing popularity of AAT. It has benefited from, and contributed to, a broader affirmation of the human-animal relationship as a psychologically meaningful relationship, though psychological research has historically focused on human benefits. The second examines the apparent correlation between human abuse of nonhuman animals and other humans (referred to in the literature as 'the link'): violence towards animals in childhood as predictor of violence towards adults in adulthood; violence towards animals in adulthood as signal of abuse in childhood; and understanding how animals and humans can be mutual victims of domestic violence.

${ }^{3}$ The more-than-human world was coined by US philosopher David Abram to refer to all forms of earthly life - animals, plants, landforms; and to make salient the fact that the world exceeds the human in ways we are nonetheless a part of, the human and more-than-human world.

${ }^{4}$ The term was originally defined by the British psychologist Richard Ryder, and taken up by Peter Singer, Ruth Harris and others in advocating a philosophical and ethical defence of animal rights (Godlovitch, Godlovitch \& Harris, 1971).

${ }^{5} \mathrm{~A}$ special issue of Feminism \& Psychology dedicated to speciesism is perhaps the closest we have come to an emerging critical psychology of human-animal relations, drawing on feminist theory (Adams, 2010; Birke, 2010; Potts \& Haraway, 2010); ecofeminism specifically (jones, 2010; Twine, 2010), and trans-species psychology (Bradshaw, 2010; Potts, 2010). Though a number of its authors have been at the forefront of interdisciplinary developments in the study of human-animal relations before and since, including Carol J Adams, Donna Haraway, Lynda Birke, Annie Potts and Gay Bradshaw, the themes and arguments established here have not yet been taken up and developed by critical psychologists in significant numbers. The various contributions to this issue are woven into the following discussion.

${ }^{6}$ For the historian Yuval Noah Harari, 'this is why the fate of farm animals is not an ethical side issue. It concerns the majority of Earth's large creatures: tens of billions of sentient beings, each with a complex world of sensations and emotions, but which live and die on an industrial production line' (Harari, 2015).

${ }^{7}$ See Ogden et al (2014) for an overview of recent research and logics of interpretation.

${ }^{8}$ See for example Helen Macdonald's H Is For Hawk (2014; winner of the Samuel Johnson Prize and the Costa Book of the Year award in 2014); Jo-Anne McArthur's We Animals photo-documentation work http://weanimals.org; Chris Jordan's Midway series http://www.chrisjordan.com/gallery/midway/\#CF000313\%2018x24; the documentaries Blackfish (dir: Cowperthwaite, 2013), Speciesism: The Movie (dir: Devries, 2013) and Unlocking the Cage (2016). We are also witnessing nascent campaigns and policies explicitly aiming to defend and extend the legal rights of nonhuman animals, such as the Nonhuman Rights Project, which is working case-bycase in the United States to try and establish legal personhood for nonhuman animals (Wise, 2015).
} 